Journal of Applied Pharmaceutical Science Vol. 5 (07), pp. 041-047, July, 2015

Available online at http://www.japsonline.com

DOI: $10.7324 /$ JAPS.2015.50707

ISSN 2231-3354 (cc) BY-NC-SA

\title{
Comparative botanical and phytochemical evaluation of Calotropis procera Linn. and Calotropis gigantea Linn. R oot
}

\author{
Sharad Srivastava, Adarsh Pratap Singh, A. K. S. Rawat \\ Pharmacognosy and Ethnopharmacology division, CSIR-National Botanical Research Institute, Lucknow-226001, India.
}

\section{ARTICLE INFO \\ Article history: \\ Received on: 06/06/2015 \\ Revised on: 02/07/2015 \\ Accepted on: 17/07/2015 \\ Available online: $27 / 07 / 2015$}

\section{Key words:}

Pharmacognosy, HPTLC,

Calotropis procera,

Calotropis gigantea.

\begin{abstract}
The present study aimed to develop pharmacognostical and phytochemical descriptors (HPTLC) of Calotropis procera and Calotropis gigantea. $\beta$-sitosterol which is one of the common terpene content and a potent antioxidant, purgative, antispasmodic and expectorant, has also been studied through a simple and high-precision method using high performance thin layer chromatography (HPTLC). This may be utilized by pharmaceutical industries for quality evaluation, ensuring successful commercial exploitation of this drug. From the present study it has been observed that both Calotropis procera and C. gigantea have similar microscopic characteristics, physico-chemical parameters showed a little variation as total ash components and extractive values are little less in $C$. gigantea. HPTLC studies also showed similar qualitative profile with some quantitative variations in total $\beta$-sitosterol, which was higher in C. gigantea $(2.79 \%)$.
\end{abstract}

\section{INTRODUCTION}

Calotropis procera Linn. and Calotropis gigantea Linn. (Family: Asclepiadaceae) known, as 'Ark or Aak' in Ayurveda are versatile medicinal plants used singly or in combination with other medicinal plants for treating a variety of ailments like irritation, different types of pain, leprosy, syphilis, intestinal worms, cough, and it also act like emetic, diaphoretic, alterative, purgative and antispasmodic activity (Caius, 1986; Das, 1996). C. procera possesses potent antioxidant and anti-inflammatory properties and has been evaluated for its hepatoprotective effect against carbon tetrachloride $\left(\mathrm{CCl}_{4}\right)$ induced hepatotoxicity in rats (Padhy et al., 2007). The hypoglycaemic property of $C$. procera has also been assessed by an oral glucose tolerance test (OGTT) in streptozotocin-diabetic rat's (Bauer et al., 1966). The root of C. procera is used as a carminative in the treatment of dyspepsia (Kumar and Arya, 2006). Further, the root barks and leaves of Calotropis species have been used by various tribes of Central

\footnotetext{
* Corresponding Author

E-mail: pharmacognosy1@ rediffmail.com
}

India as curative agents for jaundice (Samvatsar and Diwanji, 2000). The aqueous extract of the latex has been shown to inhibit cellular infiltration and provide protection against development of neoplastic changes in the transgenic mouse model of hepatocellular carcinoma (Choedon et al., 2006). The chloroform extract of the root exhibits protective activity against $\mathrm{CCl}_{4}$ induced liver damage (Basu et al., 1992).

On chemical studies, flavonoids (Chopra et al., 1956; Singh and Rastogi, 1972), triterpenoids (Pal and Sinha, 1980), volatile long chain fatty acids (Sen et al., 1992), glycosides and proteases (Kitagawa et al., 1992) have been isolated from the various parts of the plant Calotropis species. Due to the various uses of Caloptropis procera and C. gigantea, the present study was aimed to develop botanical and phytochemical descriptors for roots of both species. $\beta$-sitosterols is widely available and easy to detect and quantify among these species through HPTLC. Thus as one of the active constituent $\beta$-sitosterols, a major terpenes, has also been quantified through a simple and high-precision method using high performance thin layer chromatography (HPTLC), which may be one of the identifying parameter used by industries for quality evaluation. 


\section{MATERIALS AND METHODS}

The roots of $C$. procera and $C$. gigantea were collected at flowering stage from Lucknow, India. Materials were authenticated, and deposited in the Institute (please name the institute) herbarium (LWG No. 92906, 93248). Roots were preserved in $70 \%$ alcohol for histological studies. Microtome sections were cut and stained with safranin and fast green and photographed with Nikon F70X camera (Johansen, 1940). Physicochemical and phytochemical studies viz. total ash, acid insoluble ash, extractive values, total sugar, starch and tannin contents were carried on the shade dried powdered materials as per method described in AOAC (Anonymous, 1984; Peach and Tracy, 1955).

\section{HPTLC Studies}

Reagents were from Merk (Germany) and standard $\beta-$ sitosterol was procured from Sigma-Aldrich (Steinheim, Germany).

\section{Preparation of root extracts:}

Air dried $\left(45-55{ }^{\circ} \mathrm{C}\right)$ powdered root of $C$. procera and $C$. gigantea $(1.0 \mathrm{~g})$ in triplicate were extracted separately with $3 \times 10$ $\mathrm{ml}$ petroleum ether extract. Extracts were concentrated under vacuum, re-dissolved in methanol, filtered and finally made up of $100 \mathrm{ml}$ with petroleum ether extract prior to HPTLC analysis.

\section{Chromatographic conditions}

Chromatography was performed on Merk HPTLC precoated silica gel $60 \mathrm{GF}_{254}(20 \times 20 \mathrm{~cm})$ plates. Petroleum ether solutions of samples and standard compound $\beta$-sitosterol of known concentrations were applied to the layers as $6 \mathrm{~mm}$-wide bands positioned $15 \mathrm{~mm}$ from the bottom and $15 \mathrm{~mm}$ from side of the plate, using Camag Linomat 5 automated TLC applicator with nitrogen flow providing a delivery speed of $150 \mathrm{nl} / \mathrm{s}$ from application syringe. These conditions were kept constant throughout analysis of the samples.

\section{Detection and quantification of $\beta$-sitosterol}

Following sample application, layers were developed in a Camag twin trough glass chamber that had been pre-saturated with the mobile phase of Toluene: ethyl acetate: Methanol (8.5: 1.5: $0.5)$ till the proper separation of bands up to $8 \mathrm{~cm}$ height. After development, layers were dried with a dryer and derivatised with anisaldehyde-sulphuric acid reagent and $\beta$-sitosterol was simultaneously quantified using Camag TLC scanner model 3 equipped with Camag Wincats IV software. Following scan conditions were applied: slit width $6 \times 0.45 \mathrm{~mm}$; wavelength, $320 \mathrm{~nm}$; absorption-reflection mode. In order to prepare calibration curves, stock solution of $\beta$-sitosterol ( $1 \mathrm{mg} / \mathrm{ml}$ each) was prepared and various volumes of these solutions were analyzed through HPTLC exactly as mentioned above, calibration curves of peak area vs. concentration were also prepared. $\beta$-sitosterol (yield, $0.534 \%$ dry basis) had following values: $R_{f} 0.49$ and $r^{2} 0.9899$.

\section{RESULTS AND DISCUSSION}

Macroscopic and microscopic characters of the $C$. procera and C. gigantea root

Macroscopic and microscopic characters of roots both the species viz. C. procera and $C$. gigantea were similar and there were no marked differences which could be projected as key identifying parameters (Table1 and Fig. 1 and 2).

Table 1 Comparative Macroscopic and microscopic characters of the roots of Calotropis procera and C. gigantea

\begin{tabular}{|c|c|c|}
\hline Characters & Calotropis procera & Calotropis gigantea \\
\hline Macroscopic & $\begin{array}{l}\text { Root-rough, fissured } \\
\text { longitudinally, } \\
\text { measuring } 3 \text { to } 8 \mathrm{~cm} \text { in } \\
\text { length, } 2 \text { to } 7 \mathrm{~cm} \text { in } \\
\text { diameter: corky and soft, } \\
\text { externally yellowish- } \\
\text { grey while internally } \\
\text { white, central zone } \\
\text { cream colored. }\end{array}$ & $\begin{array}{l}\text { Root cylindrical, tortuous, } \\
\text { often branched, } \\
\text { measuring } 3 \text { to } 10 \mathrm{~cm} \text { in } \\
\text { length, } 2 \text { to } 10 \mathrm{~cm} \text { in } \\
\text { diameter; surface rough, } \\
\text { longitudinally wrinkled } \\
\text { and fissured, externally } \\
\text { yellowish white internally } \\
\text { paler. }\end{array}$ \\
\hline
\end{tabular}

Odor, characteristic: taste, bitter and

Odor, characteristic: taste, acrid.(Fig $1 \mathrm{~A})$ bitter and acrid.( Fig 2A)

\begin{tabular}{|c|c|c|}
\hline Microscopic & $\begin{array}{l}\text { Transverse section of } \\
\text { root shows outer most } \\
\text { cork tissue consisting of } \\
6-9 \text { rows of tangentially } \\
\text { elongated and radially } \\
\text { arranged cells followed } \\
\text { by 3-6 rows of } \\
\text { moderately thick-walled } \\
\text { parenchymatous cells, } \\
\text { (Fig 1B) } \\
\text { Vascular cambium } \\
\text { present just within the } \\
\text { phloem consisting of 2-5 } \\
\text { rows of thin-walled, } \\
\text { tangentially elongated } \\
\text { cells xylem forms the } \\
\text { central part of root } \\
\text { composed of vessels. } \\
\text { Tracheids, fibres and } \\
\text { xylem parenchyma, } \\
\text { vessels present } \\
\text { throughout xylem region } \\
\text { and arranged radially in } \\
\text { groups of 2-7, sometime } \\
\text { single vessels also occur, } \\
\text { ( Fig 1C, 1D, 1E) } \\
\text { Parenchymatous cell } \\
\text { rectangular to polygonal } \\
\text { with thick walls filled } \\
\text { with numerous starch } \\
\text { grain.( Fig 1F) }\end{array}$ & $\begin{array}{l}\text { Transverse section of root } \\
\text { shows stratified cork, } \\
\text { consisting of } 8 \text { to } 12 \\
\text { layers, cells of the inner } \\
\text { layers, containing } \\
\text { phellogen, } 2 \text { to } 3 \text { layered, } \\
\text { phelloderm, } \\
\text { comparatively narrow, of } \\
\text { thin walled } \\
\text { parenchymatous cells; } \\
\text { phelloderm and phellogen } \\
\text { contains laticiferous } \\
\text { tubes.(Fig } 2 \mathrm{~B} \text { ) } \\
\text { Vascular cambium, well } \\
\text { developed; xylem consist } \\
\text { of large vessels, mostly } \\
\text { isolated, radially arranged } \\
\text { (Fig } 2 \mathrm{C}, 2 \mathrm{D}, 2 \mathrm{E} \text { ), } \\
\text { parenchyma thick walled; } \\
\text { medullary rays uniseriate, } \\
\text { rarely bi-to triseriate } \\
\text { running almost parallel, } \\
\text { diverging and getting } \\
\text { broader in the phloem. } \\
\text { Parenchymatous cells } \\
\text { rectangular to polygonal } \\
\text { with fairly thick and } \\
\text { pitted walls, filled with } \\
\text { starch grain. ( Fig } 2 \mathrm{~F} \text { ) }\end{array}$ \\
\hline
\end{tabular}




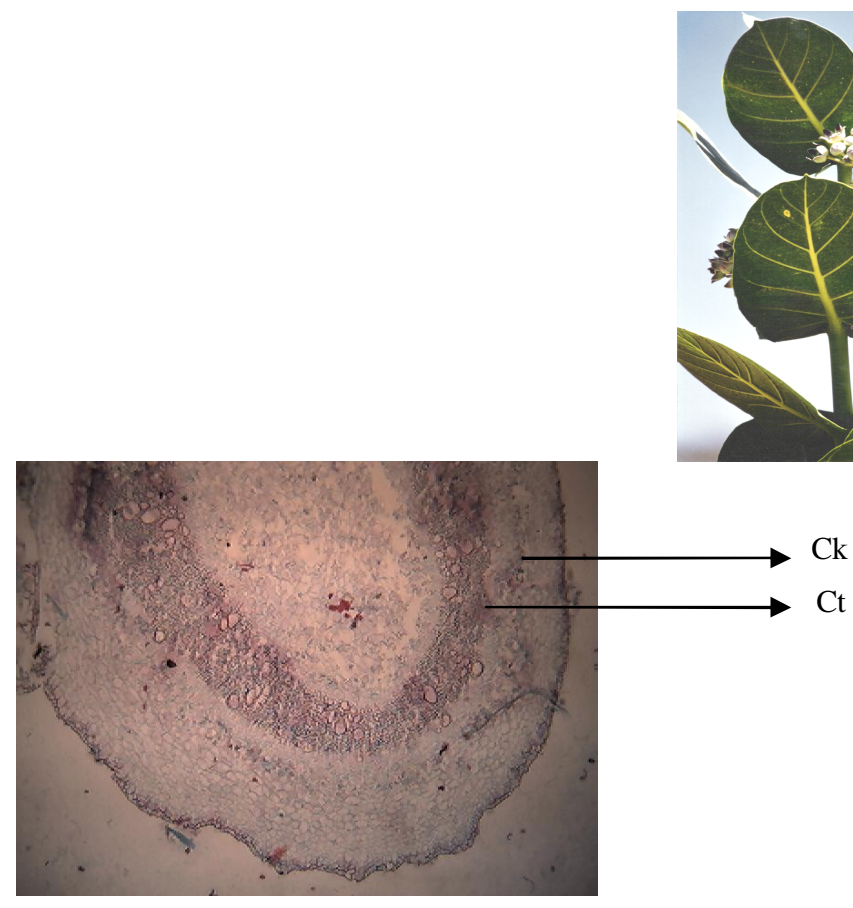

T.S. Root showing surface view

1B

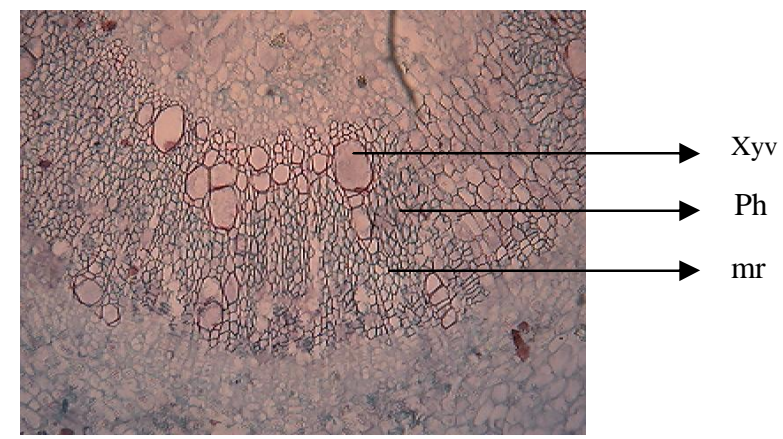

T.S. Root of showing vascular bandle

1D

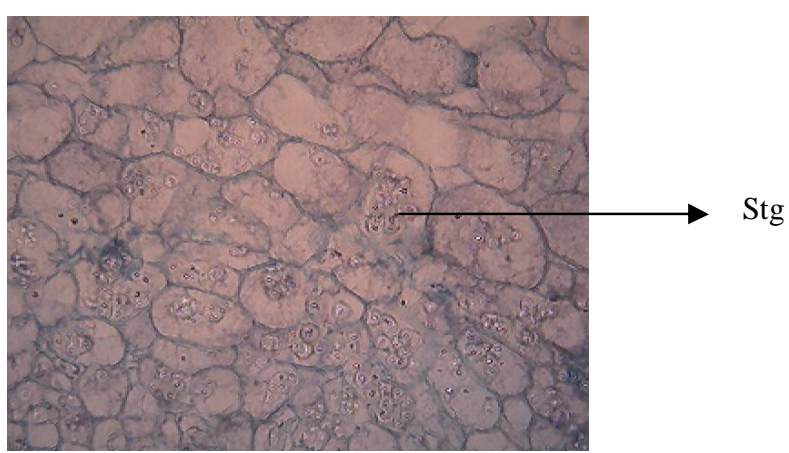

T.S. Root showing ground tissues cells in filled with starch grains

1F
$1 \mathrm{~A}$

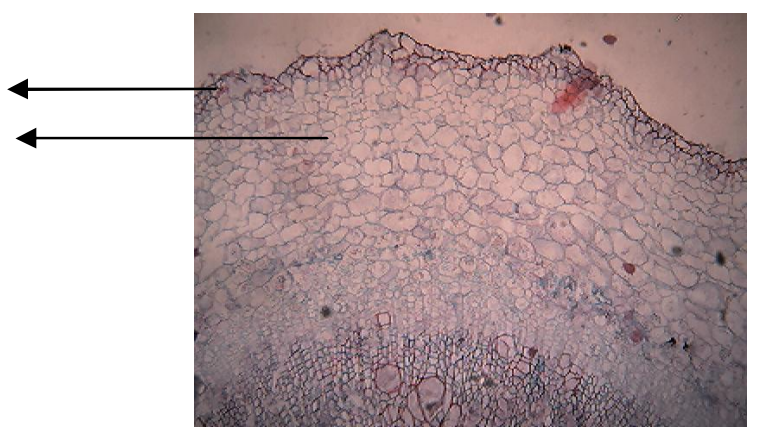

T.S. Root showing outer layering

1C

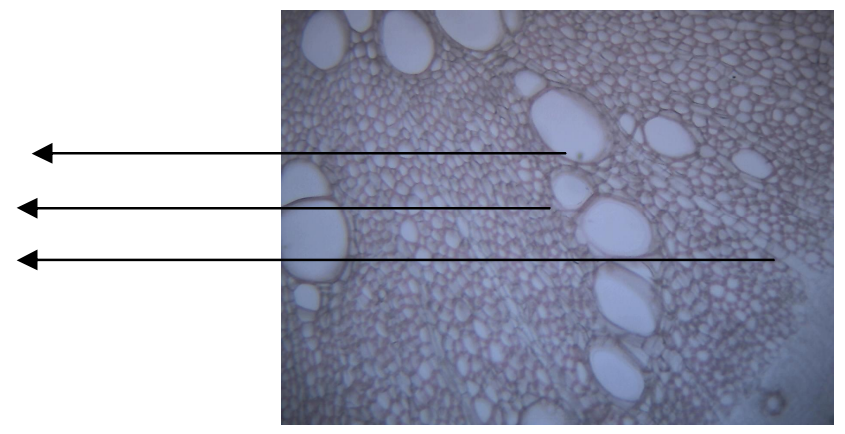

T.S. Root showing enlarge portion of vascular band

IE

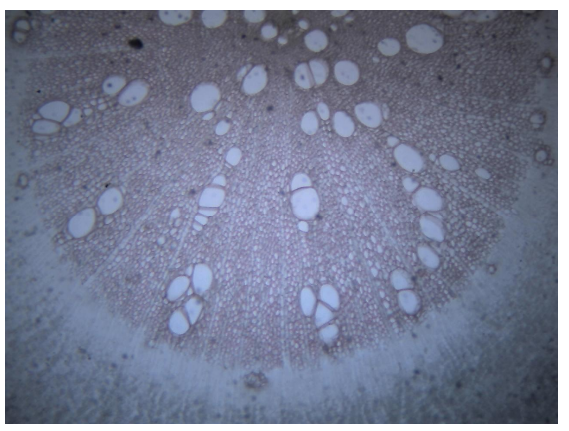

Arrangment of vascular bundle

$1 G$

Fig.1: T.S. Root of Calotropis procera (x 10X, x 40X) Abbreviation:- CC-Cork cell; CT-Cortex; MR-Medullary ray; PH-Phloem; Vs-Vessels; XyvXylem vessels; Stg-Starch grain 


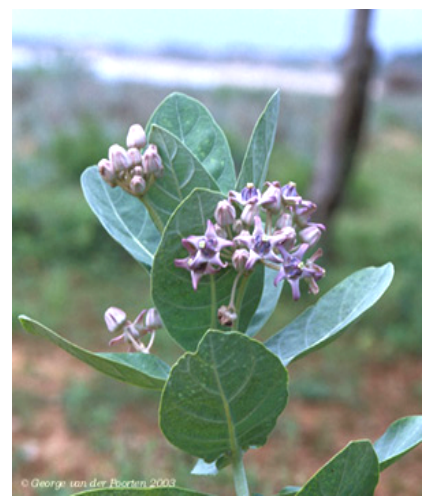

2 A

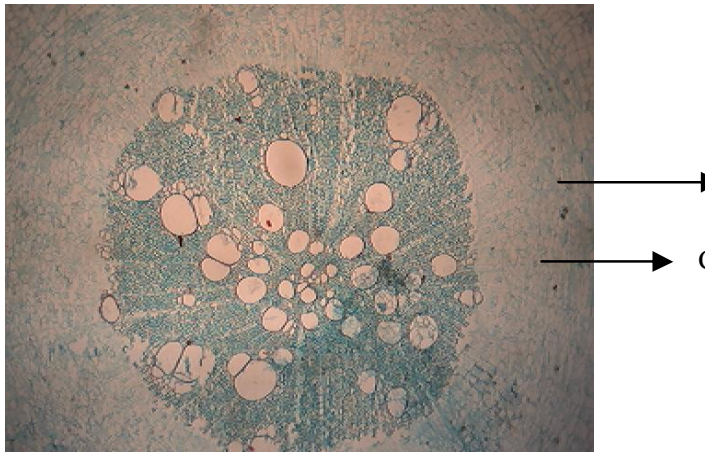

T.S. Root showing surface view 2 B

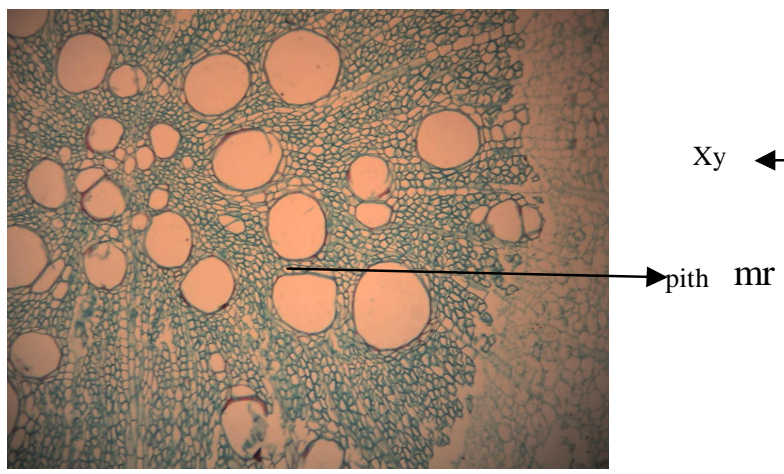

T.S. Root showing vessels

2D

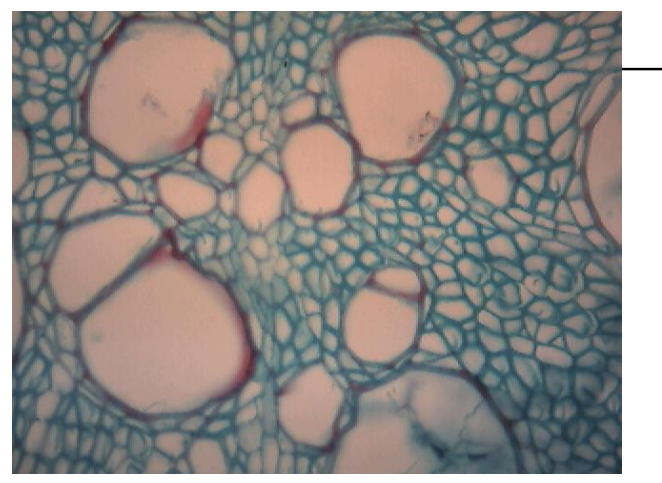

Ground tissue with xylem and Phloem

2F

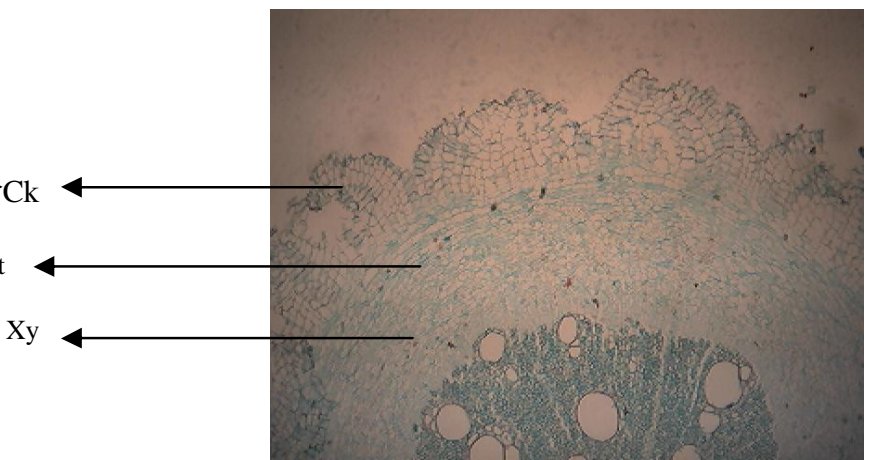

T.S. Root showing outer layering 2C

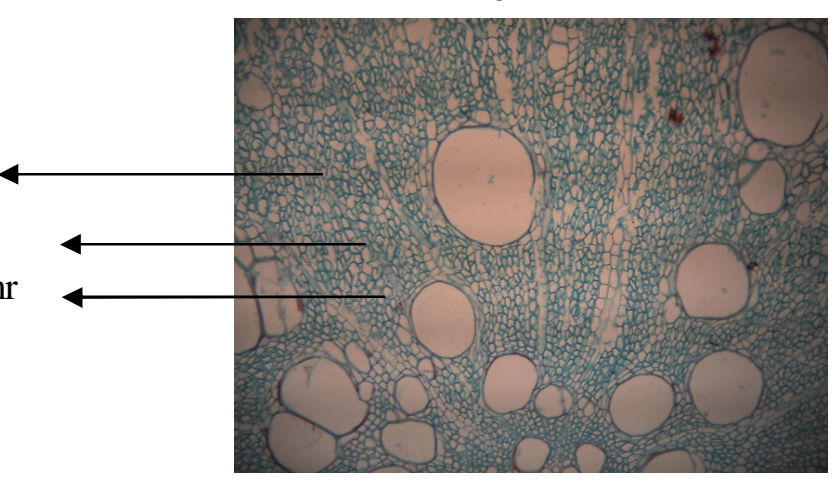

T.S. Root shows enlarge portion of vascular bundle surface view

2E

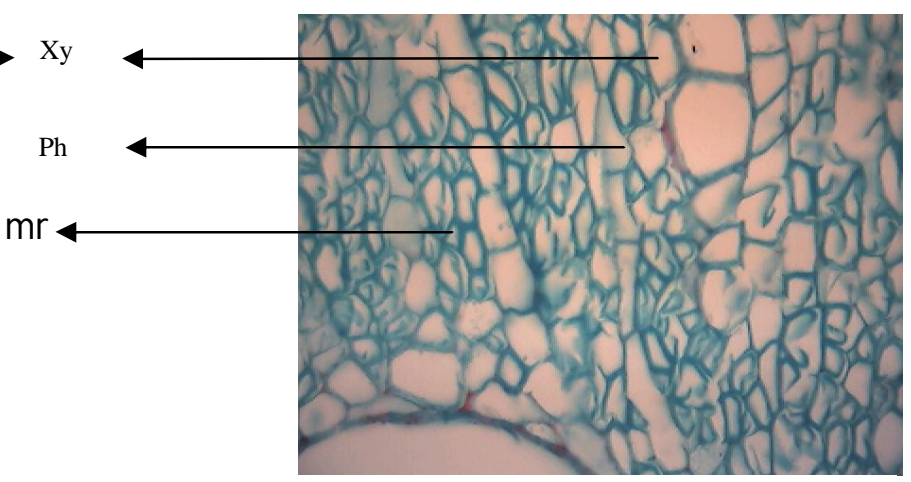

Arrangement of vascular bundles

2 G

Fig.2: T.S. Root of Calotropis gigantea (x 10X, x 40X)Abbreviation:- CC-Cork cambium; CK-Cork cell; CT-cortex; MR-Medullary ray; PH-Phloem; VsVessels; Xyv-Xylem vessels 


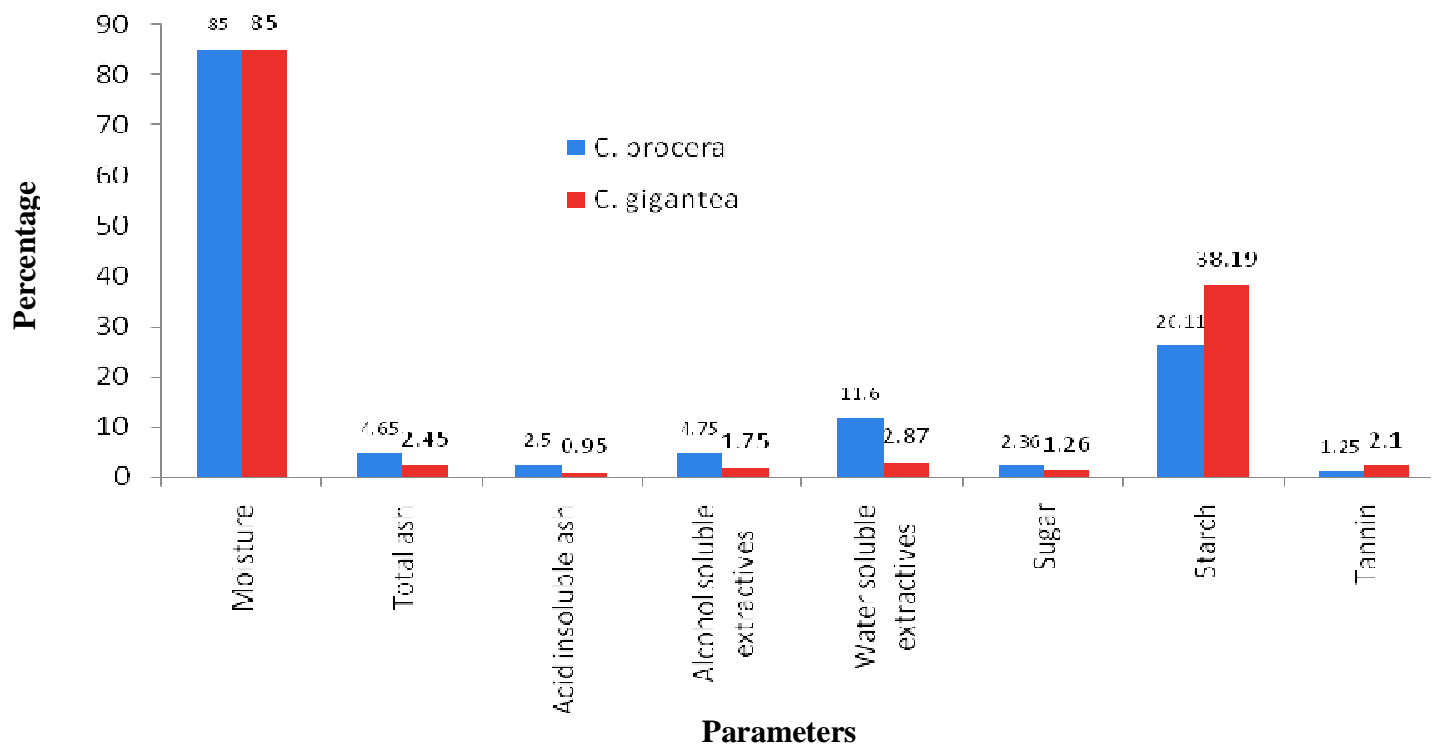

Fig. 3 Comparative physicochemical values of C. procera and C. gigantean.

\section{Physicochemical studies}

Quantitative determination of different physicochemical and phytochemical parameters revealed that:

C. procera root contains- moisture, $85 \%$; total ash, which is considered to be an important and useful parameter for detecting the presence of inorganic substances was $4.65 \%$; acid insoluble ash, 2.5\%; extractive values are indicators of the total solvent soluble component; containing alcohol soluble extractive $4.75 \%$; water soluble extractive, $11.6 \%$; sugar, $2.36 \%$; starch, $26.11 \%$ and tannins, $1.25 \%$. However $C$. gigantea composition showed some differences: moisture, $85 \%$; total ash, $2.45 \%$; acid insoluble ash, $0.95 \%$; alcohol soluble extractive, $1.75 \%$; water soluble extractive, 2.87\%; sugar, $1.26 \%$; starch, $38.19 \%$ and tannins, $2.1 \%$ (Fig. 3).

Physicochemical studies thus indicate more potentiality of $C$. procera as compared to $C$. gigantean, containing higher amount of extractive values.

\section{HPTLC Studies}

A densitometric HPTLC analysis was also performed for the development of characteristic fingerprint profile, which may be used as markers for quality evaluation and standardization of the drug. The percentage of total $\beta$-sitosterol was estimated through HPTLC methods and was higher in roots of $C$. gigantea $(2.79 \%)$ than in roots of $C$. procera $(1.07 \%)$ at $\mathrm{R}_{\mathrm{f}}$ value 0.49 and $\mathrm{r}^{2} 0.9899$ (Figs. 4-6).

It is observed that, both Calotropis procera and $C$. gigantea have similar microscopic characteristics, physicochemical studies showed a little variation; ash components and total extractive values are less in C. gigantea. However, HPTLC studies also showed similar qualitative profile with minor quantitative variations in $\beta$-sitosterol content, which was higher in C. gigantea.

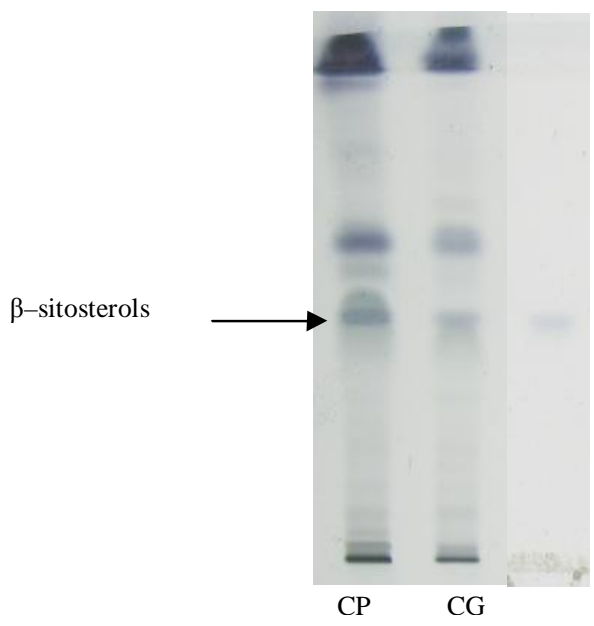

Fig. 4 HPTLC scan profile of Calotropis procera $(\mathrm{CP})$ and Calotropis gigantea (CG) (petroleum ether extract) with Reference (REF) $\beta$-sitosterols under visible light. (Plate sprayed with Anisaldehyde sulfuric acid).

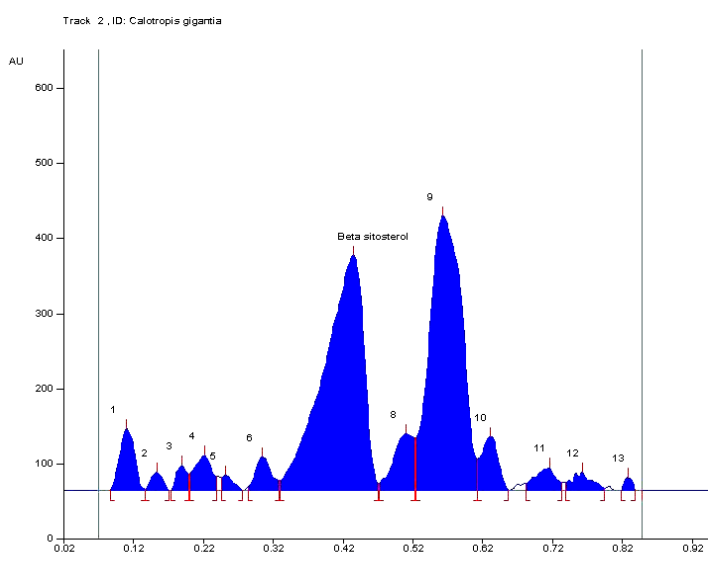

(A) 


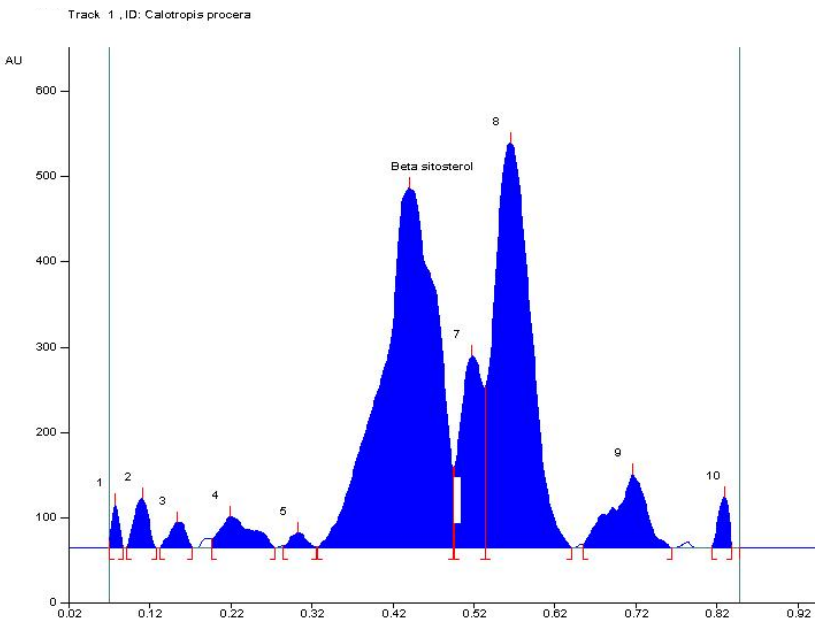

(B)

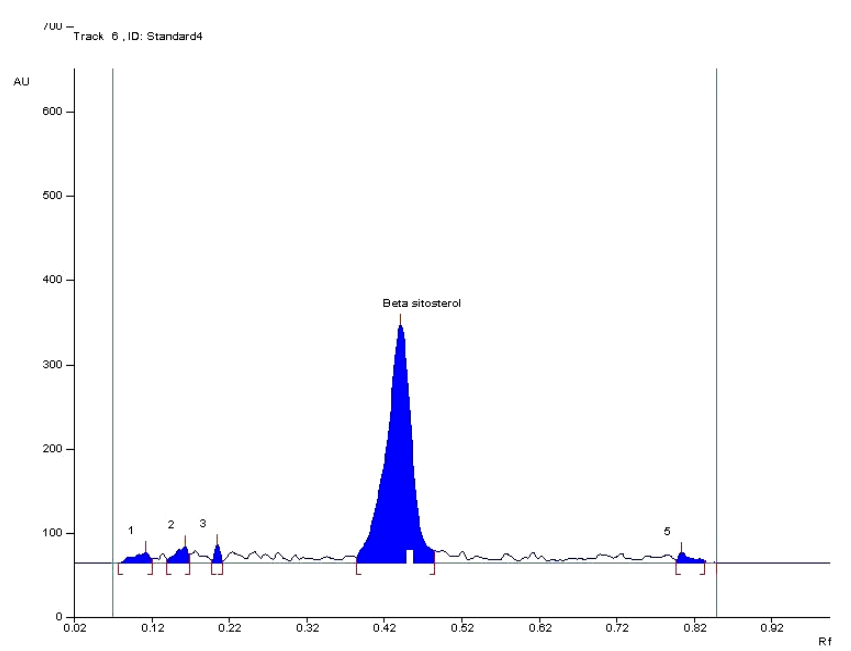

(C)

Fig. 5 Densitometric scan profile of Calotropis procera (A) and Calotropis gigantea (B) (petroleum ether extract) with standard $\beta$-sitosterols (C).

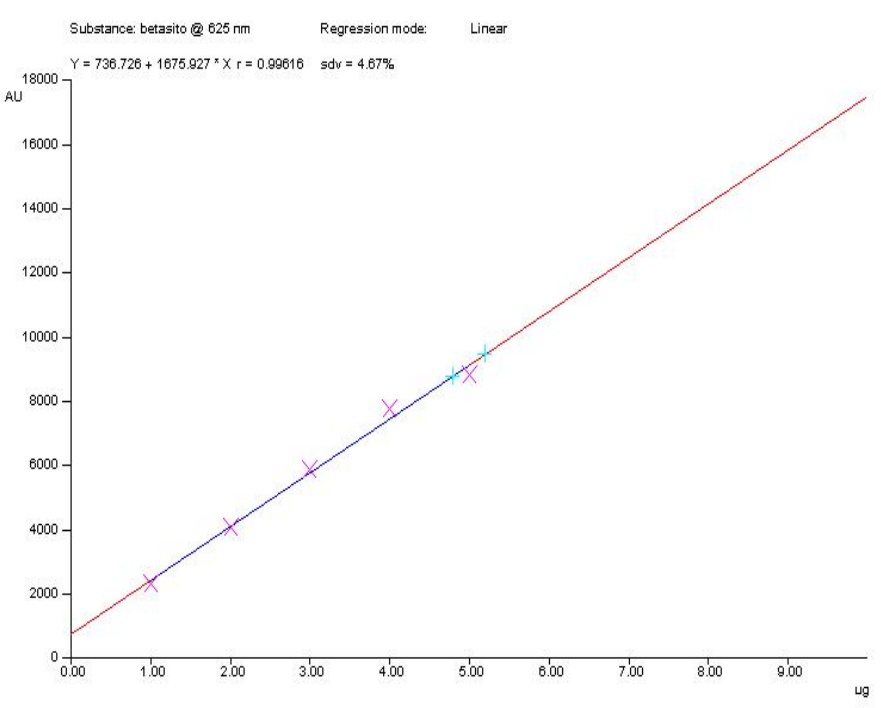

(A)

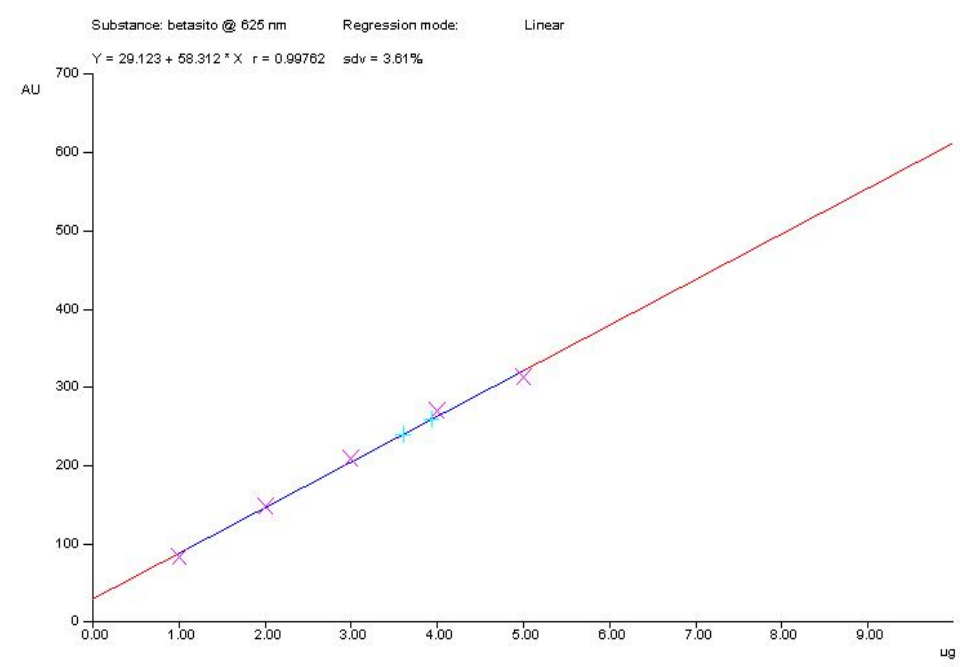

(B)

Fig. 6 Linear regression of Calotropis procera (A) and Calotropis gigantea (B) (petroleum ether extract) with standard $\beta$-sitosterols.

\section{CONCLUSION}

Above studies concludes that both the species have almost similar profile and falls in the range as mentioned in ayurvedic pharmacopoeia of India. Thus either of these species may be used in any formulations. These data may also be useful as supportive information for the exploitation of $C$. gigantea as a substitute to $C$. procera (ark). Physico-chemical and HPTLC parameters of both the species may also be useful to pharmaceutical industries for the authentication and batch to batch consistency of the commercial samples.

\section{Acknowledgements}

The authors are thankful to Director, CSIR-NBRI, Lucknow, Inida, for providing all the facilities to conduct this research work.

\section{REFERENCE}

Anonymous. Official methods of Analysis (AOAC) $4^{\text {th }}$ edn. (Association of Official Chemists, Inc., USA),1984; p.55-56.

Basu A, Sen T, Ray RN, Chaudhuri AK. Hepatoprotective effects of Calotropis procera root extract on experimental liver damage in animals. Fitoterapia.1992;63, 507-514.

Bauer AW, Kirby WMM, Sherris JC, Turck M. Antibiotic susceptibility testing by a standardized single disc method. Am. J. Clin. Pathol. 1966; 45,493-496.

Caius JF (1986). The Medicinal and Poisonous Plants of India, Scientific Publ., Jodhpur.

Choedon T, Mathan G, Arya S, Kumar VL, Kumar V. Anticancer and cytotoxic properties of the latex of Calotropis procera in a transgenic mouse model of hepatocellular carcinoma. World J. Gastroenterol.2006;12, 2517-2522.

Chopra RN, Nayar SL, Chopra IC. Glossary Indian Medicinal Plants. CSIR, New Delhi, 1956;p. 46.

Das BB (1996). Rasraj Mahodadhi, Khemraj Shri Krishnadas Prakashan, Bombay.

Johansen DA. Plant Micro Techniques (182, McGraw Hill Book Co. Inc., New York), 1940; p.102-104.

Kitagawa I, Ru-Song Z, Jony DP, Nam IB, Yasuyuki T, Mayasuki Y, Hirotaka S. Chemical structures of calotroposides A and B 
two new oxypregnaneoli- goglycosides fromthe root of Calotropis gigantea (Asclepiadaceae). Chem. Pharma. Bull.1992;40: 2007-2013.

Kumar VL, Arya S. Medicinal uses and pharmacological properties of Calotropis procera . In: J.N. Govil, Editor, Recent Progress in Medicinal Plants 11, Studium Press, Houston, Texas, USA, 2006; p.373-388.

Padhy BM, Srivastava A, Kumar VL. Calotropis procera latex affords protection against carbon tetrachloride induced hepatotoxicity in rats. J Ethnopharmacol. 2007; 113(3), 498-502.

Pal G, Sinha NK . Isolation, crystallization and properties of calotropins D1 and D2 from Calotropis gigantea. Archives of Biochemistry and Biophysics. 1980;202, 321-329.

Peach K, Tracy MV. Modern Methods of Plant Analysis (Heidelberg: Springer) $\mathbf{3}^{\text {rd }}$ and $\mathbf{4}^{\text {th }}$ vol. $1955 ; 258-261$.

Samvatsar S, Diwanji VB. Plant sources for the treatment of jaundice in the tribals of Western Madhya Pradesh of India. J. Ethnopharmacol. 2000;73, 313-316.
Sen S, Sahu NP, Mahato SB. Flavonol glycosides from Calotropis gigantea. Phytochemistry. 1992; 31, 2919-2921.

Singh B, Rastogi RP. Structure of asclepin and some observations on the NMR spectra of Calotropis glycosides. Phytochemistry.1972;11,757-762.

\section{How to cite this article:}

Srivastava S., Singh A.P., Rawat A.K.S. Comparative botanical and phytochemical evaluation of Calotropis procera Linn. and $C$. gigantea Linn. Root. J App Pharm Sci, 2015; 5 (07): 041-047. 